\title{
Photo and Plasma Activation of Dental Implant Titanium Surfaces. A Systematic Review with Meta-Analysis of Pre-Clinical Studies
}

\author{
Paolo Pesce ${ }^{1}\left(\mathbb{D}\right.$, Maria Menini $\left.^{1}{ }^{(}\right)$, Gregorio Santori ${ }^{1}$, Emanuele De Giovanni ${ }^{1}$, \\ Francesco Bagnasco ${ }^{1}$ and Luigi Canullo ${ }^{2, *(1)}$ \\ 1 Department of Surgical Sciences and Integrated Diagnostics, University of Genoa, 16132 Genoa, Italy; \\ paolo.pesce@unige.it (P.P.); maria.menini@unige.it (M.M.); gregorio.santori@unige.it (G.S.); \\ lele9-90@hotmail.it (E.D.G.); fcbagna5@hotmail.it (F.B.) \\ 2 Private Practice, Via Nizza, 46, 00198 Rome, Italy \\ * Correspondence: luigicanullo@yahoo.com; Tel.: +39-347-6201-976
}

Received: 31 July 2020; Accepted: 27 August 2020; Published: 31 August 2020 updates

\begin{abstract}
Background: Ultraviolet (UV) and non-thermal plasma functionalization are surface treatment modalities that seem able to improve osseointegration. The aim of this systematic review and meta-analysis is to assess the effect of the two methods and possible differences. Materials and Methods: The systematic research of pre-clinical animal studies was conducted up to May 2020 in the databases PubMed/Medline, Scopus and the Cochrane Lybrary. A meta-analysis was performed by using the DerSimonian-Laird estimator in random-effects models. Results: Through the digital search, 518 articles were identified; after duplicate removal and screening process 10 papers were included. Four studies evaluating UV treatment in rabbits were included in the meta-analysis. The qualitative evaluation of the included studies showed that both UV photofunctionalization and non-thermal plasma argon functionalization of titanium implant surfaces might be effective in vivo to improve the osseointegration. The meta-analysis on four studies evaluating UV treatment in rabbits showed that bone to implant contact values (expressed as standardized mean differences and raw mean differences) were significantly increased in the bio-activated groups when follow-up times were relatively homogeneous, although a high heterogeneity $\left(I^{2}>75 \%\right)$ was found in all models. Conclusions: The present systematic review and meta-analysis on pre-clinical studies demonstrated that chair-side treatment of implants with UV or non-thermal plasma appear to be effective for improving osseointegration. This systematic review supports further clinical trials on this topic.
\end{abstract}

Keywords: dental implants; UV photofunctionalization; non-thermal plasma functionalization; osseointegration

\section{Introduction}

Prosthetic rehabilitation with dental implants represents a successful therapy for the replacement of severely compromised or missing teeth, with long-term success rates above 95\% [1]. The success of dental implants largely depends on a safe integration into the maxillary bone, or rather achieving stable osseointegration over time [2]. Osseointegration is considered a demarcation response to a foreign body of Ti when the Ti implant is immobile in bone [3]. This demarcation is immune-driven and is classified as a type IV hypersensitivity [4]. Based on the original definition, the modification of a Ti implant surface implies that the surface would be more biocompatible, thereby increasing the bioaffinity of the hard tissue and accelerating the bone response to the surface. In order to improve the biological response to Ti implants, various techniques have been suggested in order to 
modify Ti surface roughness, chemistry, topography, and electrical charge, focusing on the biological performance of Ti surfaces [5-7] Higher bone-implant contact (BIC) values, better bone apposition and peri-implant bone maintenance over time were demonstrated on implants with rougher surfaces compared to machined surfaces, including stimulation of cell migration and proliferation [6-8]. BIC values in modern implants normally vary between 65 and $73 \%$ but do not reach the ideal $100 \%$ [9]. Moreover, titanium surface modifications showed, in short-term evaluations, an enhanced connective fiber attachment and a similar inflammatory response [10,11].

In recent years, various methods (ultraviolet (UV), non-thermal plasma functionalization, blasting, etching, and anodization) were proposed to improve the hydrophilicity of the titanium surface, its functionality and in order to improve its chemistry as well as reduce surface contamination $[5,12]$. Among them, (UV) and non-thermal plasma functionalization are surface treatment modalities that are able to improve all the biological aspects mentioned above and can be applied chair-side [11,13]. They allow maintaining the micro- and nano-topographical features of titanium surfaces, enhancing the biological potential before implant surgery, without damaging the surface topography. Various in vitro studies about UV and non-thermal plasma functionalization showed that this method is able to increases hydrophilicity, turning the electrostatic charge to positive, and removing hydrocarbons from the surface. Positive effects are induced also on alkaline phosphatase activity, calcium deposition, spreading of human stem cells, protein absorption capacity, osteoblast migration, attachment, spread, and proliferation [13-17].

The aim of this systematic review was to assess in pre-clinical animal studies the effect of UV photofunctionalization or non-thermal plasma functionalization on the osseointegration of dental titanium implants.

\section{Material and Methods}

This systematic review fully adhered to the guidelines of the preferred reporting of systematic reviews and meta-analyses (PRISMA) statement [18] and the protocol was registered on Prospero (CRD42020185209). The proposed focused question was: "What is the effect of UV photofunctionalization and non-thermal plasma of argon activation of titanium dental implants on osseointegration in animals?" The focused question was established according to the PICO strategy:

- Population: Healthy animals with at least one titanium dental implant.

- Intervention: Any surface activation with UV or non-thermal plasma.

- Comparison: Any type of "non-activated" titanium dental implant.

- Outcomes: Bone-to-implant contact (BIC), implant stability quotient (ISQ) or removal torque.

\subsection{Search Strategy}

An electronic search in PubMed ${ }^{\circledR} /$ MEDLINE, Scopus, and the Cochrane Central Register of Controlled Clinical Trials (CENTRAL) databases was performed starting April 2020. No publication year nor language limit was applied, so that the search could include all the available papers until 21 May 2020. The search was complemented by manual searches of the reference lists of all full-text articles selected. The following search terms were used: "photofunctionalization", "photofunctionalized", "ultraviolet(s)", "uv", "plasma(s)", "argon", and "dental implants". More details on research queries and Boolean operators are available in the electronic supplementary material (Table S1).

\subsection{Eligibility Criteria}

All articles on animals that presented a test group and a control group were considered eligible. Studies were required to have recruited a minimum of five healthy animals, have at least one titanium dental implant and have a minimum follow-up of two weeks. The studies were required to have compared implants treated with UV or non-thermal argon plasma (test group) and untreated implants. In addition, the studies to meet the inclusion criteria were required to have assessed the outcomes of 
interest (BIC value, removal torque and ISQ). Studies that did not met all the above-mentioned inclusion criteria were excluded. Review studies, retrospective studies, report studies based on questionnaires and interviews, studies without a clinical evaluation, case reports and redundant articles, studies on mini-implants and/or for orthodontic anchoring, and genomic and/or epigenomic analysis studies were also excluded.

\subsection{Selection of Studies}

Two reviewers (P.P. and E.D.G.) independently read titles and abstracts of the entries yielded from the initial electronic database search. After this initial assessment, both reviewers read separately the full-text versions of the studies that could be potentially included in this systematic review. The final selection of articles was made on the basis of the eligibility criteria described above. Any disagreement in the final selection was resolved by open discussion between both reviewers. In the case that no agreement could be reached, one of the co-author (L.C.) acted as arbiter.

\subsection{Data Extraction}

Data from the studies included in the final selection were extracted by one of the authors (E.D.G) using the Microsoft Excel spreadsheet software (Excel 16.4, Microsoft CO, Redmond, WA, USA). The accuracy of data was verified independently by another coauthor (P.P.). The following data were extracted were study design, title, author, publication year, follow-up period, number of patients (animals) and implants, implant design and surface characteristics, and the outcomes of interest (BIC, ISQ and removal torque). If data were missing, the authors of the original articles were contacted and asked to provide further details.

\subsection{Quality Assessment}

The overall quality of evidence at the outcome level in animal studies was independently assessed by two authors (E.D.G and P.P.), according to SYRCLE's RoB tool (Systematic Review Centre for Laboratory Animal Experimentation). Risk of bias in individual studies was assessed independently and in duplicate by the two coauthors as part of the data extraction process. This evaluation was conducted using the Cochrane-recommended approach for assessing risk of bias in animal intervention studies [19], including ten quality parameters: sequence generation, baseline characteristics, allocation concealment, random housing, blinding, random outcome assessment, incomplete outcome data, selective outcome reporting, and other sources of bias. Disagreements were discussed in order to aim for consensus. Each parameter was rated as: yes (low risk of bias); no (high risk of bias); or unclear (unclear risk of bias).

\subsection{Statistical Analysis}

The statistical heterogeneity among studies was expressed as $\tau^{2}$ and estimated by the Cochran's $Q$ test. The $I^{2}$ was calculated to assess variability due to heterogeneity rather than chance $\left(I^{2}=25 \%\right.$ : low; $I^{2}>25 \%$ and $=50 \%$ : moderate; $I^{2}>50 \%$ and $=75 \%$ : considerable; $I^{2}>75 \%$ : high heterogeneity). $\mathrm{H}^{2}$ was calculated as the ratio between total and sampling variability. Maximum likelihood (ML) and restricted maximum likelihood (RML) with Akaike information criteria (AIC) were returned for model fit statistics. The estimates of the effects were expressed as standardized mean difference (SMD) or raw mean difference (RMD). Study estimates were pooled with the random effects model and the DerSimonian-Laird estimator. In the random-effects models, the selected studies and their outcomes are assumed to be a random selection from a larger population of studies. A forest plot was created for each measured outcome to illustrate the effects in the meta-analysis of the different studies and the global estimation. Contour-enhanced funnel plots with Kendall's Tau and Egger's regression were used for publication bias assessment. For further evaluation of residual heterogeneity, a normal quantile-quantile (Q-Q) plot was evaluated. Statistical significance was assumed in each test with $\mathrm{P}$ 
value $<0.05$. Statistical analysis was carried out by using the $\mathrm{R}$ software (version 3.6.3; R Foundation for Statistical Computing. Vienna, Austria) with the metafor package (version 2.1-0).

\section{Results}

\subsection{Bibliographic Search and Study Selection}

The initial database search yielded a total of 518 entries; of which, 220 were found in PubMed ${ }^{\circledR} /$ MEDLINE, 285 in Scopus, and 13 in Cochrane Library. A flow chart that depicts the screening process is displayed in Figure 1. After excluding all duplicates, the total number of entries was reduced to 407. A total of 368 articles were excluded after review of title and abstract. Hence, full-text examination was conducted for 39 articles. A total of 28 additional articles were excluded after full-text review and application of the eligibility criteria. The final selection consisted of 10 articles, of which 4 were included in the meta-analyses. Detailed data for the 10 included studies are listed in Tables 1 and 2. Four authors were contacted to obtain missing information, and only one of them [20] answered.

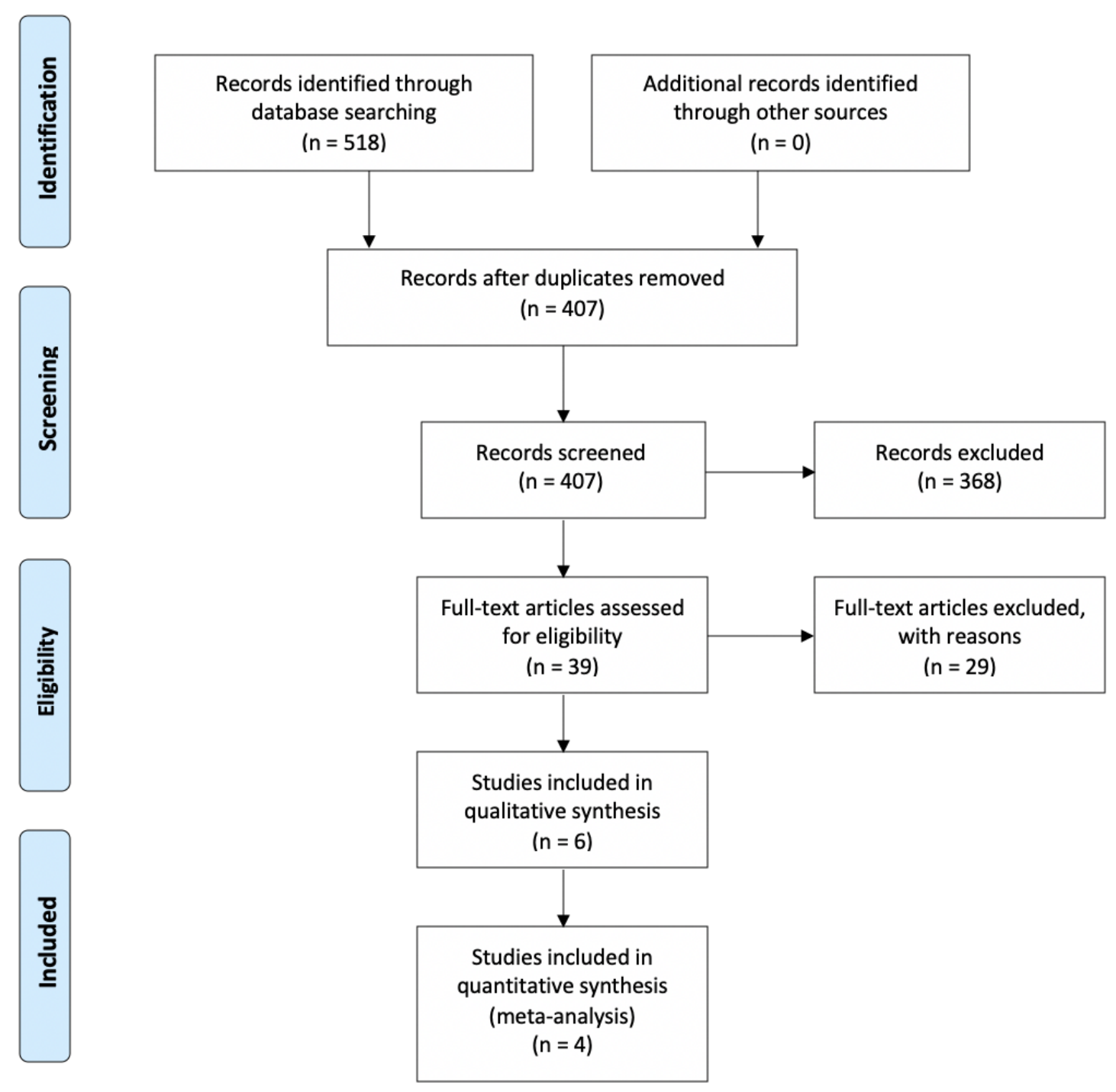

Figure 1. Preferred reporting of systematic reviews and meta-analyses (PRISMA) flow diagram related to bibliographic searching and study selection. 
Table 1. Main characteristics and outcomes of the studies on plasma included.

\begin{tabular}{|c|c|c|c|c|c|c|c|c|c|}
\hline Study Title & Reference & Year & $\begin{array}{c}\text { No of } \\
\text { Animals }\end{array}$ & Specimens & $\begin{array}{l}\text { Surface } \\
\text { Treatment }\end{array}$ & $\begin{array}{l}\text { Plasma Argon } \\
\text { Treatment }\end{array}$ & Follow-Up & Outcome & Results \\
\hline $\begin{array}{l}\text { Argon-based } \\
\text { atmospheric } \\
\text { pressure plasma } \\
\text { enhances early } \\
\text { bone response to } \\
\text { rough titanium } \\
\text { surfaces }\end{array}$ & $\begin{array}{l}\text { Coelho PG } \\
\text { et al. [21] }\end{array}$ & 2012 & $\begin{array}{l}\text { Six dogs } \\
\text { (adult } \\
\text { beagle) }\end{array}$ & $\begin{array}{l}\text { Two Ti-6Al-4V implants } \\
\text { each side. } \\
\text { The different implant } \\
\text { surfaces (Ti or Ti-Plasma) } \\
\text { were alternately placed } \\
\text { from proximal to distal at } \\
\text { distances of } 1 \mathrm{~cm} \text { from } \\
\text { each other along } \\
\text { the central region of } \\
\text { the bone. }\end{array}$ & $\begin{array}{l}\text { Alumina- } \\
\text { blasted/acid- } \\
\text { etched }\end{array}$ & $\begin{array}{c}\text { Atmospheric } \\
\text { pressure plasma } \\
\text { (CaP-plasma) } \\
\text { treatment with } \\
\text { Ar gas for } \\
\text { a period of } 60 \mathrm{~s} \\
\text { per quadrant } \\
\text { with } \\
\text { a KinPenTM } \\
\text { device }\end{array}$ & $\begin{array}{l}1 \text { and } 3 \\
\text { weeks }\end{array}$ & $\begin{array}{c}\text { BIC (\%) } \\
\text { BAFO } \\
\text { (bone area } \\
\text { fraction } \\
\text { occupacy) }\end{array}$ & $\begin{array}{l}\text { No significant difference was } \\
\text { found for BIC and BAFO } \\
\text { between surfaces at } 1 \text { week. } \\
\text { At } 3 \text { weeks in vivo, bone } \\
\text { formation in close contact to } \\
\text { the implant surface (BIC) was } \\
\text { strongly observed in } \\
\text { the Ti-plasma group, where } \\
\text { an increase of over 300\% was } \\
\text { observed when compared to } \\
\text { the control ( } p<0.001) \text {. No } \\
\text { significant differences were } \\
\text { observed in BAFO ( } p>0.14 \text { ), } \\
\text { although an improvement of } \\
30 \% \text { was observed for } \\
\text { the Ti-plasma group }\end{array}$ \\
\hline $\begin{array}{l}\text { Assessment of } \\
\text { a chair-side } \\
\text { argon-based } \\
\text { non-thermal } \\
\text { plasma treatment } \\
\text { on the surface } \\
\text { characteristics and } \\
\text { integration of } \\
\text { dental implants } \\
\text { with textured } \\
\text { surfaces }\end{array}$ & $\begin{array}{c}\text { Teixeira H et } \\
\text { al. [22] }\end{array}$ & 2012 & $\begin{array}{l}\text { Six dogs } \\
\text { (adult } \\
\text { beagle) }\end{array}$ & $\begin{array}{c}\text { Three root-form } \\
\text { endosseous grade IV } \\
\text { titanium alloy implants } \\
\text { placed into each limb. } \\
\text { Test: } 20 \text { sand } 60 \mathrm{~s} \\
\text { plasma-treated implants; } \\
\text { control: untreated } \\
\text { implants. }\end{array}$ & $\begin{array}{l}\text { Alumina-blasted } \\
\text { and } \\
\text { acid-etched } \\
\text { surface }\end{array}$ & $\begin{array}{l}\text { Twenty or sixty } \\
\text { seconds of } \\
\text { non-thermal } \\
\text { plasma per } \\
\text { quadrant } \\
\text { applied with } \\
\text { a KinPenTM } \\
\text { device }\end{array}$ & $\begin{array}{l}2 \text { and } 4 \\
\text { weeks }\end{array}$ & $\begin{array}{l}\text { Removal } \\
\text { torque } \\
(\mathrm{Ncm})\end{array}$ & $\begin{array}{l}\text { Torque value at } 2 \text { weeks: } \\
\text { control: } 35 ; \\
\text { plasma: } 20 \mathrm{~s}-43 ; \\
\text { plasma: } 60 \mathrm{~s}-55 \text {. } \\
\text { Torque value at } 4 \text { weeks: } \\
\text { control: } 43 \text {; } \\
\text { plasma: } 20 \mathrm{~s}-67 ; \\
\text { plasma } 60 \mathrm{~s}-72 .\end{array}$ \\
\hline
\end{tabular}


Table 1. Cont

\begin{tabular}{|c|c|c|c|c|c|c|c|c|c|}
\hline Study Title & Reference & Year & $\begin{array}{c}\text { No of } \\
\text { Animals }\end{array}$ & Specimens & $\begin{array}{c}\text { Surface } \\
\text { Treatment }\end{array}$ & $\begin{array}{c}\text { Plasma Argon } \\
\text { Treatment }\end{array}$ & Follow-Up & Outcome & Results \\
\hline $\begin{array}{l}\text { Osseointegration } \\
\text { assessment of } \\
\text { chairside } \\
\text { argon-based non } \\
\text { thermal } \\
\text { plasma-treated } \\
\text { Ca-P coated } \\
\text { dental implant }\end{array}$ & $\begin{array}{c}\text { Giro G et al. } \\
\text { [23] }\end{array}$ & 2013 & $\begin{array}{l}\text { Six dogs } \\
\text { (adult } \\
\text { beagle) }\end{array}$ & $\begin{array}{l}\text { Two Ti-6Al-4V implants } \\
\text { each side. } \\
\text { Different implant surfaces } \\
\text { were alternately placed } \\
\text { from proximal to distal at } \\
\text { distances of } 1 \mathrm{~cm} \text { from } \\
\text { each other along } \\
\text { the central region of } \\
\text { the bone, and the start } \\
\text { surface site (CaP or } \\
\text { CaP-Plasma) was } \\
\text { alternated between } \\
\text { animals. The implant } \\
\text { distribution resulted in an } \\
\text { equal number of implants } \\
\text { for } 1 \text { and } 3 \text { weeks. }\end{array}$ & $\begin{array}{l}\text { Calcium- } \\
\text { phosphate } \\
\text { (CaP) }\end{array}$ & $\begin{array}{c}\text { Ar gas at } \\
\text { atmospheric } \\
\text { pressure for } \\
\text { a period of } 20 \mathrm{~s} \\
\text { per quadrant } \\
\text { with } \\
\text { a KinPenTM } \\
\text { device }\end{array}$ & $\begin{array}{l}1 \text { and } 3 \\
\text { weeks }\end{array}$ & $\begin{array}{c}\text { BIC (\%) } \\
\text { BAFO } \\
\text { (bone area } \\
\text { graction } \\
\text { occupacy) }\end{array}$ & $\begin{array}{c}\text { No significant difference was } \\
\text { found for BIC and BAFO } \\
\text { between surfaces at } 1 \text { week. } \\
\text { At } 3 \text { weeks, BIC and BAFO } \\
\text { were strongly observed in } \\
\text { the CaP-plasma group. } \\
\text { The morphologic findings for } \\
\text { both } 1 \text { and } 3 \text { weeks were } \\
\text { supported by } \\
\text { the morphometric results at } \\
\text { the } 3 \text {-week period, as } \\
\text { CaP-plasma BIC increased by } \\
\text { more than } 100 \% \text { and an } \\
\text { improvement of } 82 \% \text { was } \\
\text { found for BAFO when } \\
\text { compared to the CaP group. }\end{array}$ \\
\hline $\begin{array}{l}\text { Hard and soft } \\
\text { tissue changes } \\
\text { around implants } \\
\text { activated using } \\
\text { plasma of argon: } \\
\text { a histomorphometric } \\
\text { study in dog }\end{array}$ & $\begin{array}{l}\text { Canullo L et } \\
\text { al. [24] }\end{array}$ & 2018 & $\begin{array}{c}\text { Eight dogs } \\
\text { (adult } \\
\text { beagle) }\end{array}$ & $\begin{array}{c}\text { For each hemi-mandible, } \\
\text { four implants with a ZirTi } \\
\text { surface were used; } \\
\text { two implants were treated } \\
\text { with argon plasma (test), } \\
\text { while the other two } \\
\text { implants were left } \\
\text { untreated (control). }\end{array}$ & ZirTi surface & $\begin{array}{l}\text { Treated for } 12 \\
\text { min at room } \\
\text { temperature } \\
\text { with plasma of } \\
\text { argon in } \\
\text { a plasma reactor } \\
\text { (Diener } \\
\text { electronic) }\end{array}$ & $\begin{array}{l}1 \text { and } 2 \\
\text { months }\end{array}$ & $\begin{array}{l}\text { BIC }(\%) \\
\text { old bone } \\
\quad \text { total } \\
\text { amount of } \\
\text { mineralized } \\
\text { bone }\end{array}$ & $\begin{array}{c}\text { One month of healing: } \\
\text { new bone in close contact } \\
\text { with the implant surface: } \\
\text { treated }(60.1 \% \pm 15.6 \% ; 95 \% \\
\text { CI } 56.5 \%-78.0 \%) \text {; untreated } \\
(57.2 \% \pm 13.1 \% \text {; } 95 \% \text { CI } \\
49.3 \%-67.5 \%)(p=0.400) \text {. } \\
\text { Old bone: treated }(4.4 \% \pm \\
\text { 3.0\%; } 95 \% \text { CI. } 2 \%-5.4 \%) ; \\
\text { untreated }(3.4 \% \pm 3.1 \% \text {; } 95 \% \\
\text { CI. } 6 \%-4.9 \%)(p=726) . \\
\text { Total amount of mineralized } \\
\text { bone: treated } \\
\text { (95\% CI } 59.5 \%-82.3 \%) ; \\
\text { untreated }(95 \% \text { CI } \\
53.3 \%-73.5 \%)(p=0.208) \text {. } \\
\text { Two months of healing of } \\
\text { new bone: treated sites: } \\
72.5 \% \pm 12.4 \%(95 \% \text { CI } \\
69.6 \%-86.8 \%) ;\end{array}$ \\
\hline
\end{tabular}


Table 1. Cont.

\begin{tabular}{|c|c|c|c|c|c|c|c|c|c|}
\hline Study Title & Reference & Year & $\begin{array}{c}\text { No of } \\
\text { Animals }\end{array}$ & Specimens & $\begin{array}{l}\text { Surface } \\
\text { Treatment }\end{array}$ & $\begin{array}{c}\text { Plasma Argon } \\
\text { Treatment }\end{array}$ & Follow-Up & Outcome & Results \\
\hline & & & & & & & & & $\begin{array}{c}\text { untreated: } 64.7 \% \pm 17.3 \% \\
\text { (95\% CI 59.4\%-83.3\% }(p= \\
0.012) . \\
\text { Old bone: treated sites: } 3.1 \% \\
\pm 1.7 \%(95 \% \text { CI } 1.8 \%-4.2 \%) \\
\text { untreated sites: } 3.8 \% \pm 1.9 \% \\
\quad(95 \% \text { CI } 3.2 \%-5.8 \%) \\
\quad(p=0.270) . \\
\text { Total amount of mineralized } \\
\text { bone: treated: } 75.6 \% \pm 13.0 \% \\
\text { (95\% CI } 73.3 \%-91.3 \%) ; \\
\text { untreated } 68.4 \% \pm 16.8 \% \\
\text { (95\% CI } 64.2 \%-87.6 \%) .\end{array}$ \\
\hline $\begin{array}{l}\text { Effects of non } \\
\text { thermal plasma } \\
\text { on sandblasted } \\
\text { titanium dental } \\
\text { implants in beagle } \\
\text { dogs }\end{array}$ & $\begin{array}{l}\text { Hung YW et } \\
\text { al. [25] }\end{array}$ & 2018 & $\begin{array}{l}\text { Nine dogs } \\
\text { (adult } \\
\text { beagle) }\end{array}$ & $\begin{array}{l}\text { Four implants in each dog; } \\
\text { control group: one } \\
\text { implant withot } \\
\text { non-thermal plasma was } \\
\text { inserted into each jaw; } \\
\text { test group: one implant } \\
\text { treated with non-thermal } \\
\text { plasma was inserted into } \\
\text { each jaw. }\end{array}$ & $\begin{array}{l}\text { Sandblasting } \\
\text { and etching }\end{array}$ & $\begin{array}{l}\text { Non-thermal } \\
\text { plasma } \\
\text { apparatus (Line } \\
\text { through ISO } \\
\text { 9001) generates } \\
\text { plasma in } \\
\text { a dielectric } \\
\text { barrier. Each } \\
\text { implant receive } \\
\text { 60s of plasma } \\
\text { spray }\end{array}$ & $\begin{array}{c}4,8 \text { and } \\
12 \text { weeks }\end{array}$ & ISQ Value & $\begin{array}{c}\text { ISQ values: } \\
\text { Control group: } \\
\text { Initial: } 68.04 \pm 3.37 \\
4 \text { weeks: } 66.53 \pm 7.40 \\
\text { 8 weeks: } 69.20 \pm 2.55 \\
12 \text { weeks: } 74.20 \pm 2.68 \\
\text { Plasma group: } \\
\text { Initial: } 67.36 \pm 0.52 \\
\text { 4 weeks: } 70.17 \pm 0.76 \\
\text { 8 weeks: } 71.50 \pm 1.41 \\
12 \text { weeks: } 77.00 \pm 5.87\end{array}$ \\
\hline
\end{tabular}


Table 2. Main characteristics and outcome of included studies about UV.

\begin{tabular}{|c|c|c|c|c|c|c|c|c|c|}
\hline Study Title & Reference & Year & $\begin{array}{c}\text { No of } \\
\text { Animals }\end{array}$ & Specimens & Surface Treatment & $\begin{array}{c}\text { UV } \\
\text { Treatment }\end{array}$ & Follow-Up & Outcome & Results \\
\hline $\begin{array}{l}\text { Photo-induced } \\
\text { hydrophilicity } \\
\text { enhances } \\
\text { initial cell behavior } \\
\text { and early bone } \\
\text { apposition. }\end{array}$ & $\begin{array}{l}\text { Sawase, T } \\
\text { et al. [26] }\end{array}$ & 2008 & $\begin{array}{l}\text { Six rabbits } \\
\text { (tibia) }\end{array}$ & $\begin{array}{l}\text { One implant each } \\
\text { side of the tibia; } \\
\text { cpTi screw implants } \\
\text { (Nobel Biocare RP } \\
\text { Mark III fixtures; } \\
\text { Nobel Biocare AB, } \\
\text { Göteborg, Sweden). }\end{array}$ & $\begin{array}{l}\text { Post-annealed from } \\
\text { the titanium implant; } \\
\text { tetraisoproxide } \\
\text { plasma by the plasma } \\
\text { source; ion } \\
\text { implantation }\end{array}$ & $\begin{array}{l}\text { UV irradiation } \\
\text { for } 24 \mathrm{~h}\end{array}$ & 2 weeks & $\begin{array}{l}\text { BIC } \\
(\%)\end{array}$ & $\begin{array}{l}\text { BIC untreated: } 17.97 \% \text {; } \\
\text { BIC UV: treated } 28.2 \% \text {. }\end{array}$ \\
\hline $\begin{array}{l}\text { The effect of } \\
\text { ultraviolet C } \\
\text { irradiation via } \\
\text { a bactericidal } \\
\text { ultraviolet sterilizer } \\
\text { on an anodized } \\
\text { titanium implant. A } \\
\text { study in rabbits }\end{array}$ & $\begin{array}{l}\text { Park K.H } \\
\text { et al. [27] }\end{array}$ & 2013 & $\begin{array}{l}\text { Fourteen } \\
\text { rabbits } \\
\text { (tibia) }\end{array}$ & $\begin{array}{l}\text { Twenty-five titanium } \\
\text { discs and } 56 \text { screw } \\
\text { tipe implants. Each } \\
\text { rabbits received four } \\
\text { control or test } \\
\text { implants (UV } \\
\text { treated). }\end{array}$ & Anodized implants & $\begin{array}{l}\text { UV irradiation } \\
\text { via a } 15 \mathrm{~W} \\
\text { lamp for } 24 \mathrm{~h}\end{array}$ & $\begin{array}{l}4 \text { and } 12 \\
\text { weeks }\end{array}$ & $\begin{array}{l}\text { BIC } \\
(\%)\end{array}$ & $\begin{array}{l}\text { Four-week mean value: } \\
\text { control group (12): } 42.92 \% \text {; } \\
\text { test group (12): } 55.11 \% \text {. } \\
\text { Twelve-week value: } \\
\text { control group (14): } 55.81 \% \text {; } \\
\text { test group (14): } 57.78 \% .\end{array}$ \\
\hline $\begin{array}{l}\text { The in vivo bone } \\
\text { response of } \\
\text { ultraviolet-irradiated } \\
\text { titanium implants } \\
\text { modified with } \\
\text { spontaneusly formed } \\
\text { nanostructures }\end{array}$ & $\begin{array}{l}\text { Shen J et } \\
\text { al. [20] }\end{array}$ & 2016 & $\begin{array}{l}\text { Forty } \\
\text { rabbits } \\
\text { (femur } \\
\text { and tibia) }\end{array}$ & $\begin{array}{c}\text { A total of } 160 \\
\text { screw-shaped } \\
\text { implants divided in } 5 \\
\text { groups: } \\
\text { (1) SLA new } \\
\text { (2) SLA old } \\
\text { (3) modified SLA } \\
\text { (4) UV SLA } \\
\text { (5) UV modified SLA. }\end{array}$ & $\begin{array}{l}\text { Sandblasted and } \\
\text { acid-etched }\end{array}$ & $\begin{array}{l}\text { UV irradiation } \\
\text { via a } 15 \mathrm{~W} \\
\text { bactericidial } \\
\text { lamp for } 24 \mathrm{~h}\end{array}$ & $\begin{array}{l}3 \text { and } 6 \\
\text { weeks }\end{array}$ & $\begin{array}{l}\text { BIC } \\
(\%) \\
\text { RT } \\
\text { (removal } \\
\text { torque) }\end{array}$ & $\begin{array}{c}\text { BIC mean value at } 3 \\
\text { weeks: } \\
\text { group (1): } 40.05 \% \\
\text { group (2): } 30.2 \% \\
\text { group (3): } 35.3 \% \\
\text { group (4): } 59.6 \% \\
\text { group (5): } 61.8 \% \\
\text { BIC mean value at } 6 \\
\text { weeks: } \\
\text { group (1): } 41.6 \% \\
\text { group (2): } 31.3 \% \\
\text { group (3): } 39.3 \% \\
\text { group (4): } 69.5 \% \\
\text { group (5): } 72.0 \% \\
\text { Torque removal mean at } \\
\text { value } 3 \text { weeks: } \\
\text { group (1): } 42 \\
\text { group (2): } 30 \\
\text { group (3): } 39\end{array}$ \\
\hline
\end{tabular}


Table 2. Cont.

\begin{tabular}{|c|c|c|c|c|c|c|c|c|c|}
\hline Study Title & Reference & Year & $\begin{array}{c}\text { No of } \\
\text { Animals }\end{array}$ & Specimens & Surface Treatment & $\begin{array}{c}\text { UV } \\
\text { Treatment }\end{array}$ & Follow-Up & Outcome & Results \\
\hline & & & & & & & & & $\begin{array}{l}\text { group (4): } 70 \\
\text { group (5): } 90 \\
\text { Toque removal mean } \\
\text { value at } 6 \text { weeks: } \\
\text { group (1): } 70 \\
\text { group (2): } 42 \\
\text { group (3): } 60 \\
\text { group (4): } 82 \\
\text { group (5): } 105\end{array}$ \\
\hline $\begin{array}{l}\text { Photofunctionalised } \\
\text { Ti6Al4V implants } \\
\text { enhance early phase } \\
\text { osseointegration. }\end{array}$ & $\begin{array}{l}\text { Yamauchi, } \\
\text { R et al. } \\
\text { [28] }\end{array}$ & 2017 & $\begin{array}{l}\text { Five rats } \\
\text { (femur) }\end{array}$ & $\begin{array}{l}\text { One implant each } \\
\text { side; implant made } \\
\text { from pure Ti and } \\
\text { Ti6Al4V (B. Braun } \\
\text { Aesculap Japan Co., } \\
\text { Ltd. Tokyo, Japan). }\end{array}$ & $\begin{array}{l}\text { Specimens: pure Ti } \\
\text { and Ti6Al4V with } \\
\text { average surface } \\
\text { roughness values of } \\
0.66 \text { and } 0.34 \mu \mathrm{m}, \\
\text { respectively }\end{array}$ & $\begin{array}{l}\text { Exposure to } \\
\text { UV irradiation } \\
\text { for } 15 \text { min } \\
\text { using a photo } \\
\text { device } \\
\text { (TheraBeam } \\
\text { Affinity; } \\
\text { Ushio Inc., } \\
\text { Tokyo, Japan) } \\
\text { at an intensity } \\
\text { of } 3 \mathrm{~mW} / \mathrm{cm}^{2}\end{array}$ & $\begin{array}{l}2 \text { and } 4 \\
\text { weeks }\end{array}$ & $\begin{array}{c}\text { BIC } \\
\text { value } \\
(\mathrm{BV} / \mathrm{TV} \\
\%)\end{array}$ & $\begin{array}{c}\text { Pure Ti value: } \\
\text { Untreated 2-week value: } \\
\text { 39.8\%; } \\
\text { treated 2-week value: } \\
56.8 \% \text {. } \\
\text { Untreated 4-week value: } \\
\text { 61.6\%; } \\
\text { treated 4-week value: } \\
\text { 80.7\%. } \\
\text { Ti6Al4V value: } \\
\text { Untreated 2-week value: } \\
44.4 \% ; \\
\text { treated 2-week value: } \\
65.0 \% \text {; } \\
\text { untreated 4-week value: } \\
58.6 \% ; \\
\text { treated 4-week value: } \\
\text { 76.3\%. }\end{array}$ \\
\hline $\begin{array}{l}\text { Effects of ultraviolet } \\
\text { Photoactivation on } \\
\text { osseointegration of } \\
\text { commercial pure } \\
\text { titanium dental } \\
\text { implant after } 8 \text { weeks } \\
\text { in a rabbit model }\end{array}$ & $\begin{array}{l}\text { Sanchez-Perez } \\
\text { A et al. } \\
\text { [29] }\end{array}$ & 2020 & $\begin{array}{l}\text { Five } \\
\text { rabbits }\end{array}$ & $\begin{array}{l}\text { Twenty commercial } \\
\text { implants. }\end{array}$ & $\begin{array}{c}\text { Group 1: as received; } \\
\text { group 2: } \\
\text { UV treated }\end{array}$ & $\begin{array}{c}\text { A 6W UVC } \\
\text { source for } 15 \\
\text { min (Analizer } \\
\text { VL 6c) }\end{array}$ & 8 weeks & $\begin{array}{l}\mathrm{BIC} \\
(\%)\end{array}$ & $\begin{array}{l}\text { BIC mean value: } \\
\text { Control group: } 26.835 \% \text {; } \\
\text { test group } 24.225 \% \text {. }\end{array}$ \\
\hline
\end{tabular}




\subsection{Description of Included Studies}

Detailed data for the 10 included studies are listed in Tables 1 and 2. All studies included in the present review are studies performed on test case animals, with a study group and a control group. Four studies were performed on rabbits $[20,26,27,29]$ and one on rats [28]. Five studies were performed on beagle dogs [21-25] The studies included in the review showed wide variations regarding length of the follow-up. The majority of them had a follow-up of a few weeks only and only two had a follow-up up to 12 weeks $[25,27]$.

\subsection{Excluded Studies}

Out of the 39 papers for which the full-text was analyzed, 29 articles [13,30-57] were excluded from the systematic review (Table A1). The main reasons for exclusion were the following: small sample size, (articles that recruited less than five animals); outcome, (articles that did not evaluated BIC value, removal torque, or ISQ); and specimens, (articles that did not evaluated titanium dental implants).

\subsection{Quality Assessment}

According to SYRCLE's RoB tool (Systematic Review Centre for Laboratory Animal Experimentation), risk of bias of animal studies is assessed and displayed in Figure 2 [19]. No article showed low risk of bias for all domains.

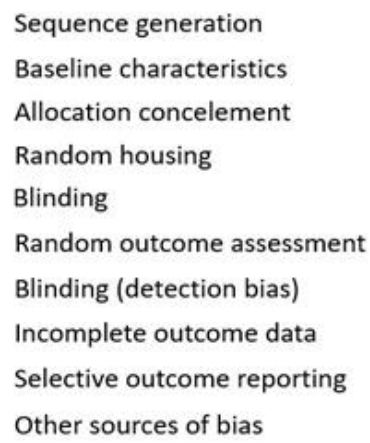

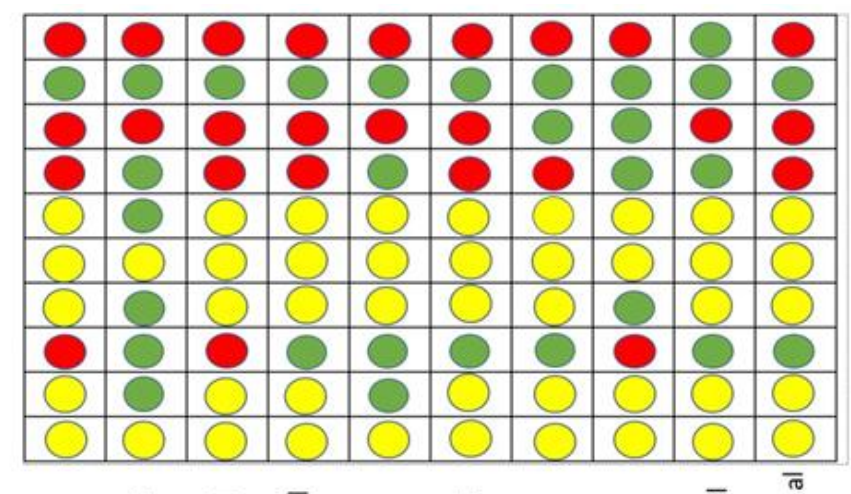

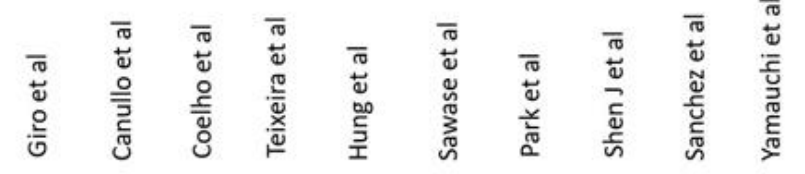

$$
\text { Low risk } \bigcirc \text { Unclear risk } \bigcirc \text { High risk }
$$

Figure 2. Quality assessment of included animal studies.

\subsection{Qualitative Assessment of Outcomes}

Differences in bone-to-implant contact (BIC) values between test and control groups were evaluated in eight studies [20,22-28]. In these studies, the functionalization treatment of the implant surfaces, both by UV and by non-thermal plasma, led to better BIC results than the control group. Only one study in rabbits reported lower BIC values in the test groups (UV-treated) than in the control group [29]. In fact, in the study by Sanchez-Perez et al., at 8 weeks, a minimal variation in the BIC values between the test group and the control group was noted, with BIC values of $26.835 \%$ for the control group and $24.225 \%$ for the test group. Differences in ISQ values between test group and control group were evaluated in one study [25], in which ISQ values were higher in the test group at 8 and 12 weeks of follow-up compared to the group control. Differences in removal torque values between the test group 
and control group were evaluated in two studies [20,22]. In all studies the removal torque $(\mathrm{Ncm})$ values were higher in the test groups than in the control groups.

\subsection{Quantitative Assessment of Outcomes}

The meta-analysis was conducted only if at least three articles presented the same treatment method for functionalization of the implant surface, and the same kind of sample and the same outcome of interest (BIC value) was evaluated. Following these criteria, four articles were included in the quantitative evaluation $[20,26,27,29]$, as reported in the PRISMA flow chart (Figure 1). Based on the peculiarities of the follow-up recorded in some of the studies meeting the enrollment criteria (follow-up at different time-points in two studies, with slightly different numbers of implants), the analysis was conducted on multiple datasets identified on the basis of the different follow-up periods in order to even the follow-up time-points, applying the criterion of $n=1$ study with unique follow-up for a single dataset. Following this approach, four datasets were assessed. The first dataset (Table S2) took into consideration the following follow-up periods: 2 weeks [26], 4 weeks [27], 3 weeks [20], and 8 weeks [29]. The second dataset (Table S3) resulted in 2 weeks [26], 12 weeks [27], 6 weeks [20], and 8 weeks [29]. The third dataset (Table S4) returned 2 weeks [26], 4 weeks [27], 3 weeks [20], and 8 weeks [29]. Finally, the fourth dataset (Table S5) resulted in 2 weeks [26], 12 weeks [27], 6 weeks [20], and 8 weeks [29].

\subsubsection{First Dataset}

The first dataset included 33 animals and 84 implants (Table S2). The pooled SMD of the random-effects model was 1.20 (95\% CI: 0.10-2.30) $(p=0.032)$, while the model fit statistics were $\mathrm{ML}=-5.91(\mathrm{AIC}=15.82)$ and $\mathrm{RML}=-4.87(\mathrm{AIC}=13.75)$. The model showed a high heterogeneity $\left(I^{2}\right.$ $\left.=80.33 \% ; H^{2}=5.08 ; \tau^{2}=0.996 ; Q=15.25 ; p=0.002\right)$. In the normal $\mathrm{Q}-\mathrm{Q}$ plot, no study was outside the confidence area (Figure S5A). The forest plot is presented in Figure 3. Publication bias assessment returned no statistical significance for Kendall's Tau $(p=0.333)$ or Egger's regression $(p=0.076)$ (Figure S9A). The results of the same model with RMD as effect size are presented in the Supplementary Material (Figures S1, S5B and S9B).

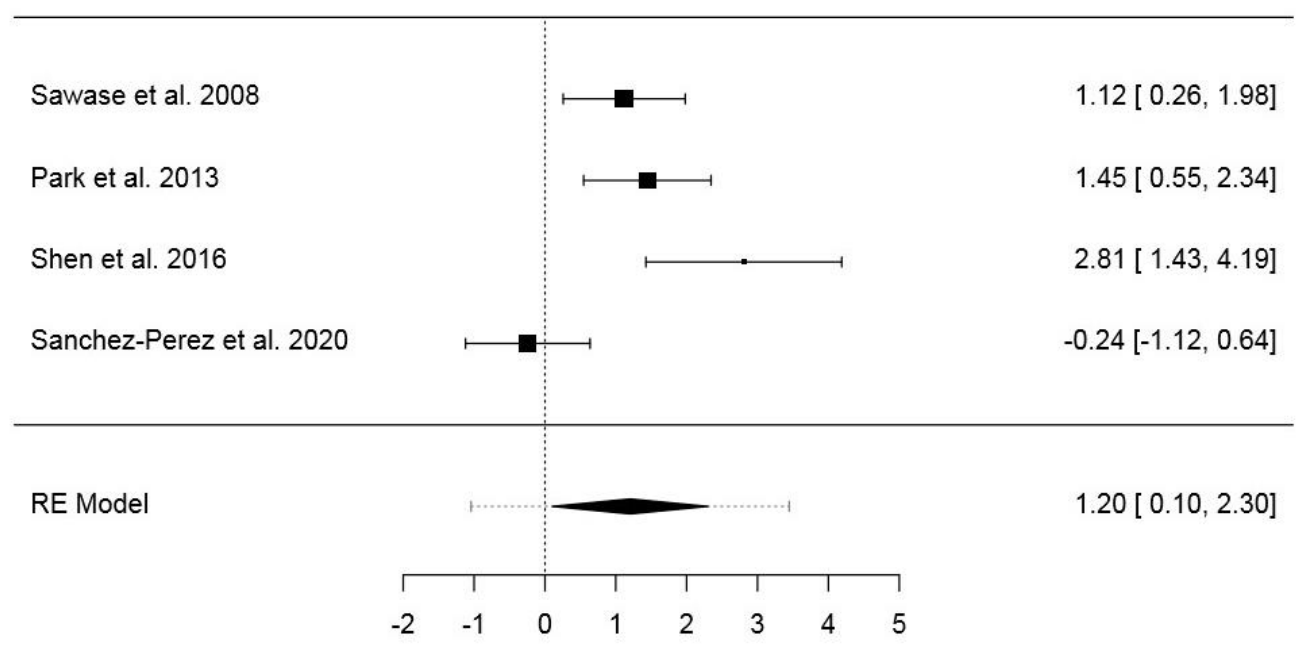

Figure 3. Forest plot for the random-effects model with the DerSimonian-Laird estimator in the first dataset (effects size: standardized mean difference of the bone-implant contact).

\subsubsection{Second Dataset}

The second dataset included 34 animals and 88 implants (Table S3 (Supplementary Materials)). The pooled SMD of the random-effects model was 1.13 (95\% CI: $-0.19-2.46)(p=0.095)$, while the model fit statistics were $\mathrm{ML}=-7.84(\mathrm{AIC}=19.68)$ and $\mathrm{RML}=-6.62(\mathrm{AIC}=17.24)$. The model showed 
a high heterogeneity $\left(I^{2}=86.66 \% ; H^{2}=7.49 ; \tau^{2}=1.524 ; Q=22.48 ; p \leq 0.001\right)$. In the normal $Q-Q$ plot, one study resulted outside the confidence area (Figure S6A). The forest plot is presented in Figure 4. Publication bias assessment returned no statistical significance for Kendall's Tau ( $p=0.750)$, differently from Egger's regression $(p<0.001)$ (Figure S10A). The results of the same model with RMD as effect size are presented in the Supplementary Material (Figures S2, S6B and S10B).

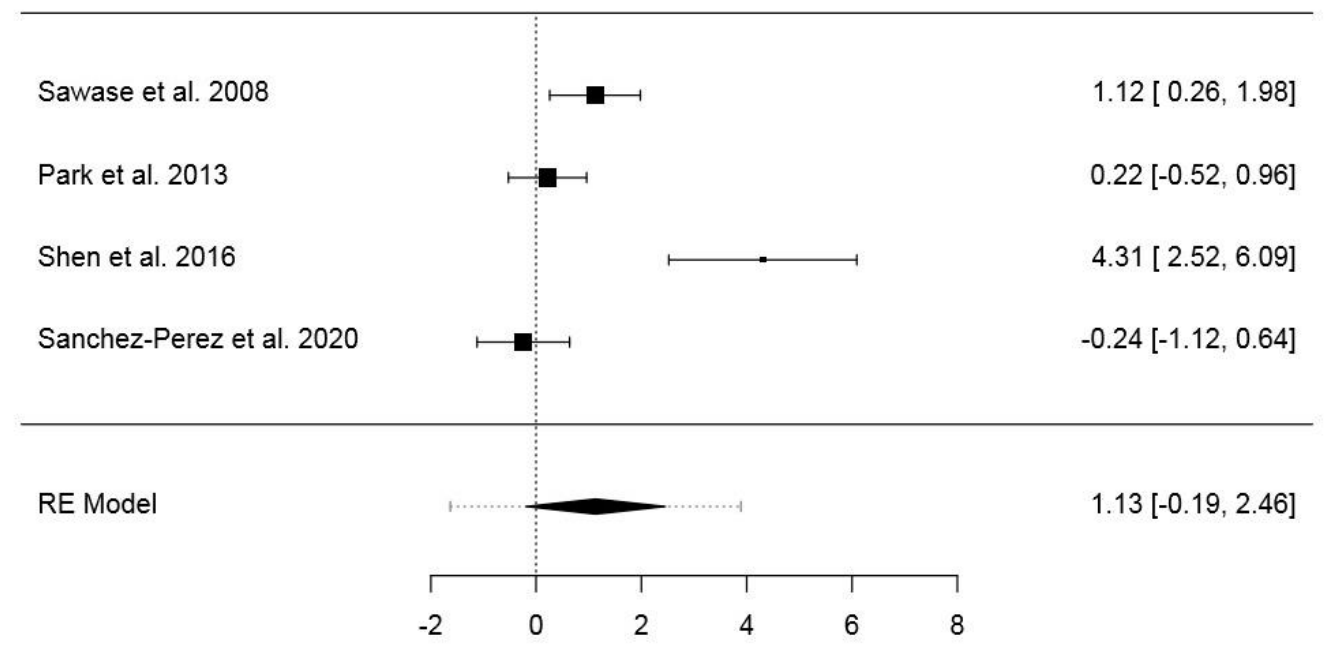

Figure 4. Forest plot for the random-effects model with the DerSimonian-Laird estimator in the second dataset (effects size: standardized mean difference of the bone-implant contact).

\subsubsection{Third Dataset}

The third dataset included 33 animals and 84 implants (Table S4). The pooled SMD of the random-effects model was 1.09 (95\% CI: 0.11-2.07) $(p=0.028)$, while the model fit statistics were $\mathrm{ML}=-5.25(\mathrm{AIC}=14.51)$ and $\mathrm{RML}=-4.34(\mathrm{AIC}=12.68)$. The model showed a high heterogeneity $\left(I^{2}=76 \% ; H^{2}=4.17 ; \tau^{2}=0.746 ; Q=12.50 ; p=0.006\right)$. In the normal $Q-Q$ plot, no study was outside the confidence area (Figure S7A (Supplementary Materials)). The forest plot is presented in Figure 5. Publication bias assessment returned no statistical significance for Kendall's Tau ( $p=0.333)$ or Egger's regression ( $p=0.181$ ) (Figure S11A). The results of the same model with RMD as effect size are presented in the Supplementary Material (Figures S3, S7B and S11B).

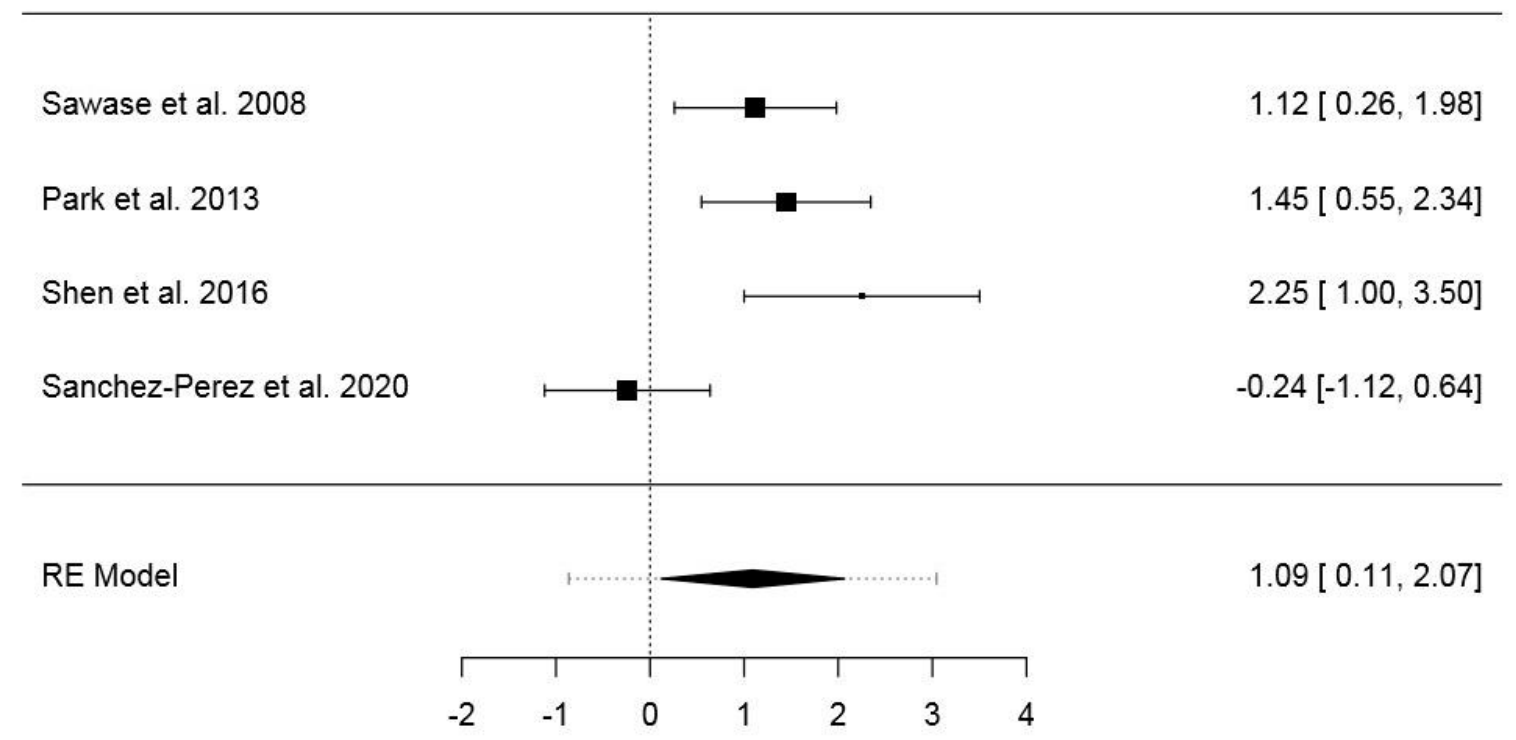

Figure 5. Forest plot for the random-effects model with the DerSimonian-Laird estimator in the third dataset (effects size: standardized mean difference of the bone-implant contact). 


\subsubsection{Fourth Dataset}

The fourth dataset included 34 animals and 88 implants (Table S5). The pooled SMD of the random-effects model was 0.85 (95\% CI: $-0.19-1.89)(p=0.110)$, while the model fit statistics were $\mathrm{ML}=-5.98(\mathrm{AIC}=1.95)$ and $\mathrm{RML}=-5.00(\mathrm{AIC}=13.99)$. The model showed a high heterogeneity $\left(I^{2}\right.$ $\left.=80.32 \% ; H^{2}=5.08 ; \tau^{2}=0.89 ; Q=15.24 ; p=0.002\right)$. In the normal $\mathrm{Q}-\mathrm{Q}$ plot, no study was outside the confidence area (Figure S8A). The forest plot is presented in Figure 6. Publication bias assessment returned no statistical significance for Kendall's Tau $(p=0.750)$, differently from Egger's regression $(p=0.021)$ (Figure S12A). The results of the same model with RMD as effect size are presented in the Supplementary Material (Figures S4, S8B and S12B).

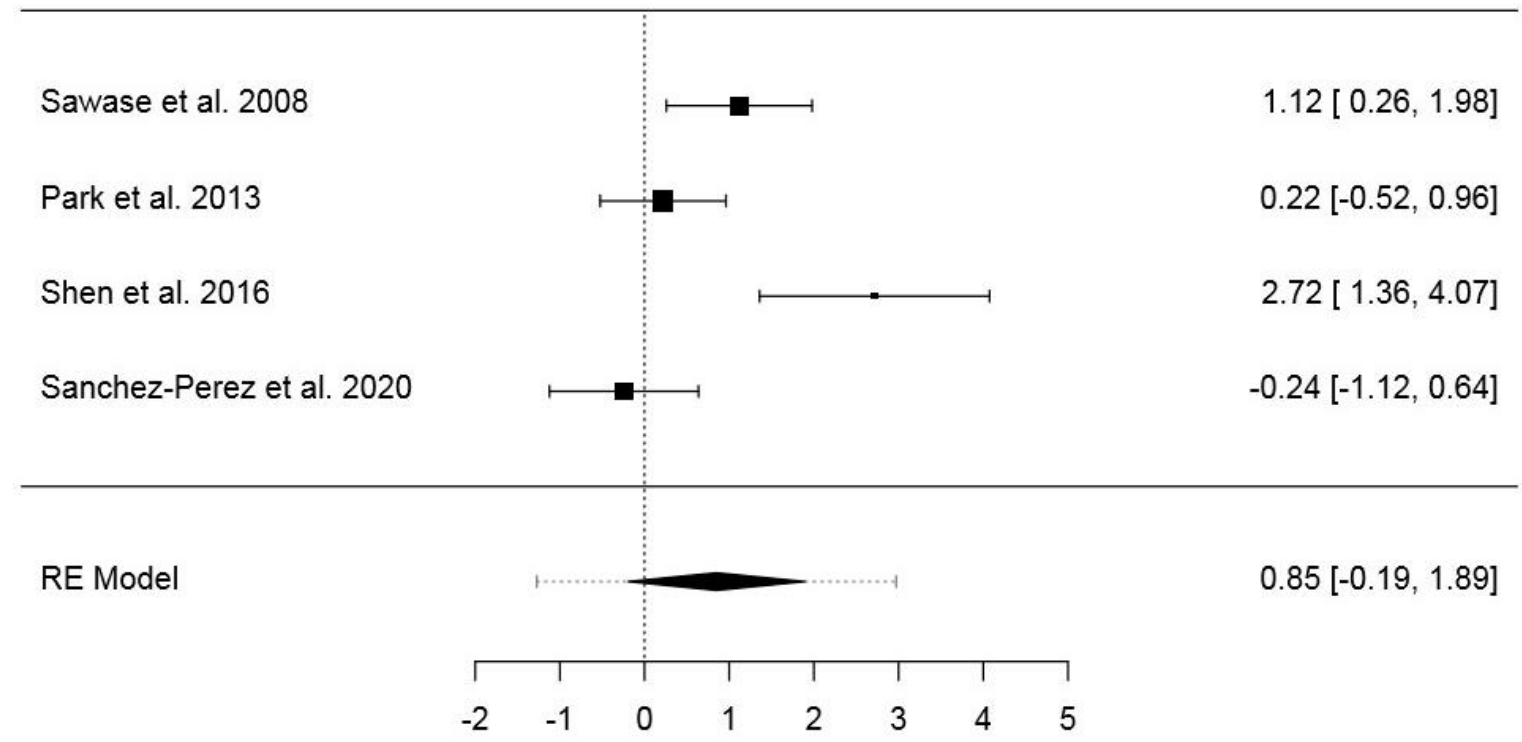

Figure 6. Forest plot for the random-effects model with the DerSimonian-Laird estimator in the fourth dataset (effects size: standardized mean difference of the bone-implant contact).

\section{Discussion}

This systematic review focused on the evaluation of the effects of the functionalization treatment of the implant surfaces by means of UV or non-thermal Plasma on the peri-implant bone, and, more specifically, it investigated the effects on the biological process of osseointegration, as evaluated by BIC, ISQ (implant stability quotient), and removal torque. The eligibility criteria of the studies were first determined so as to include in the systematic review studies with the following: a minimum number of five animals, which had at least one titanium dental implant; a test group subjected to treatment with UV or non-thermal plasma and a control group; analysis the BIC value with a minimum follow-up of two weeks; and ISQ and/or removal torque. A qualitative analysis of the results was performed on all included studies, and a quantitative analysis was performed on 4 of the 10 included studies.

\section{Summary of the Results and Possible Limitations}

The qualitative analysis of the results shows for the majority of the studies, higher BIC (bone-to-implant contact) values in the test groups subjected to the functionalization treatment of the implant surfaces by UV or by non-thermal plasma. With regard to studies that used UV treatment [20,26-28], BIC values were better in the test group when compared to the control group at all the time points. Two studies that used treatment with non-thermal plasma [21,23] did not find significant differences in BIC between the test and the control group at the first follow-up (1 week), but they found significant differences in BIC values between the test and the control group at the second follow-up ( 3 weeks) with better values for the test group. 
The third study evaluating non-thermal plasma treatment [24] showed higher BIC values in the test group than in the control group at both 4 and 8 weeks of healing. Only one study [29] reported slightly higher BIC values for the control group than for the UV-treated test group. Despite this, there is a greater homogeneity of the BIC in the test group compared to the control group.

ISQ values were evaluated in a single animal study [25], demonstrating higher ISQ values in the test group subjected to functionalization treatment with non-thermal argon plasma compared to the control group.

Removal values were evaluated in two studies: one [20] evaluating UV functionalization treatment, and one [22] using functionalization treatment with non-thermal argon plasma. In all these three studies, the removal torque $(\mathrm{Ncm})$ values were higher in the test groups than in the control groups.

The meta-analysis was conducted for four studies [20,26,27,29], in which the test groups were subjected to UV treatment. The assessed outcome was the BIC value. A quantitative analysis of the studies in which the test groups underwent treatment with non-thermal plasma, presenting the same outcome of interest, was not possible due to the lack of data. For the studies included in the quantitative evaluation, following the differences in the follow-up, an analysis was conducted on several datasets identified on the basis of the different follow-up periods without prejudice to the criterion of $n=1$ study, and with unique follow-up for each individual dataset [26]. The meta-analysis showed statistically significant difference in favor of the test groups in the first and third dataset, for both SMD and RMD as effect size. No significant differences occurred in the second and fourth dataset. The relatively more homogeneous follow-up of the first and third dataset may have contributed to the model outcomes. However, in all models, a high heterogeneity was found, although the highest $I^{2}$ and $Q$ values occurred for the second and fourth dataset. Normal Q-Q plots showed overall satisfactory profiles, with all or most of the studies falling within the confidence region in each model. Notably, no significance for publication bias was returned by the models evaluated by entering the first and third dataset. Data from the present meta-analysis confirmed the importance to increase surface energy to stimulate bone formation through the exposition to UV. However, a similar effect was obtained also through the activation of the electronic mantel following plasma of argon bio-activation [49]. Additionally, it must be noted that despite the increase in surface energy, these procedures were proven to not affect the bacterial contamination of the implant surface (or bone augmentation material), confirming to finally result positive for bone growth [58-62].

Limitations can be attributed to the high heterogeneity of the studies, the applied methodology, (including numerosity of the samples, especially in studies on UV treatment), and type of samples tested (dental implants or disks), etc. Different types of devices and time of application were used to functionalize the surfaces of the implants. Three studies $[20,26,27]$ used a source of UV radiation for $24 \mathrm{~h}$; two studies $[28,29]$ used a UV-emitting device for $15 \mathrm{~min}$. However, even if a different application time was employed, all studies obtained better results in the UV-treated groups. The minimum irradiation time required to obtain a clinically appreciable effect is yet to be determined [29]. Three studies [21-23] used a plasma device (KinPen Device) for $60 \mathrm{~s}$ or for $20 \mathrm{~s}$. The third study [24] used a plasma reactor (Diener electronic) for $12 \mathrm{~min}$. The fourth study [25] used a Plasma reactor (Line through ISO 9001) for $60 \mathrm{~s}$. Further studies should evaluate the better application time of UV and Plasma in order to standardize the technique.

Another limitation is the definition of osseointegration itself, which is a clinical outcome and not a histological one. Surrogates for osseointegration are used to conduct research, for example, BIC and ISQ. These are measures of specific elements of the bone-implant interface; however, there is little evidence that BIC correlates with long-term clinical outcomes of dental implant therapy, and the use of ISQ, although widely used, remains enigmatic [63].

Further limitations are secondary to the incomplete publication of data. BIC and standard deviation values are not reported in three studies $[20,21,23]$ The authors of the aforementioned articles were contacted to supplement the missing data; however, only the BIC values of a single article were obtained [20]. 
From the clinical point of view, both methods can be used chair-side by the clinician before implant insertion.

Both the investigated techniques of functionalization are easy to apply, cost effective and are devoid of contraindications.

This study and data from animal experiments presented promising outcomes for UV and non-thermal plasma functionalization. An improvement in osseointegration might be expected following biofunctionalization of dental implants. However, it must be emphasized that these results must be taken with caution, as data from animal studies cannot be directly extrapolated to the clinical practice, and the clinical efficacy of these treatments is yet to be established. Human studies are needed to confirm if biofunctionalization of dental implants might affect the bone-implant interface in the short and in the long term.

\section{Conclusions}

Based on the qualitative and quantitative assessment conducted as part of the present systematic review, it can be concluded that the treatment of titanium dental implant surfaces using UV or non-thermal plasma may represent an effective method for improving the osseointegration process. Randomized human studies are needed to validate the obtained results.

Supplementary Materials: The following are available online at http://www.mdpi.com/2077-0383/9/9/2817/s1, Table S1: Research query and their outputs; Table S2: First dataset entered in the meta-analysis; Table S3: Second dataset entered in the meta-analysis; Table S4: Third dataset entered in the meta-analysis; Table S5: Fourth dataset entered in the meta-analysis; Figure S1: Forest plot for the random-effects model with the DerSimonian-Laird estimator in the first dataset (effects size: raw mean difference of the bone-implant contact); Figure S2: Forest plot for the random-effects model with the DerSimonian-Laird estimator in the second dataset (effects size: raw mean difference of the bone-implant contact); Figure S3: Forest plot for the random-effects model with the DerSimonian-Laird estimator in the third dataset (effects size: raw mean difference of the bone-implant contact); Figure S4: Forest plot for the random-effects model with the DerSimonian-Laird estimator in the fourth dataset (effects size: raw mean difference of the bone-implant contact); Figure S5: Normal Q-Q plots related to the random-effects models with the DerSimonian-Laird estimator in the first dataset; Figure S6: Normal Q-Q plots related to the random-effects models with the DerSimonian-Laird estimator in the second dataset; Figure S7: Normal Q-Q plots related to the random-effects models with the DerSimonian-Laird estimator in the third dataset; Figure S8: Normal Q-Q plots related to the random-effects models with the DerSimonian-Laird estimator in the fourth dataset; Figure S9: Funnel plots for the publication bias assessment related to the random-effects models with the DerSimonian-Laird estimator in the first dataset; Figure S10: Funnel plots for the publication bias assessment related to the random-effects models with the DerSimonian-Laird estimator in the second dataset; Figure S11: Funnel plots for the publication bias assessment related to the random-effects models with the DerSimonian-Laird estimator in the third dataset; Figure S12: Funnel plots for the publication bias assessment related to the random-effects models with the DerSimonian-Laird estimator in the fourth dataset.

Author Contributions: Conceptualization, P.P. and L.C.; methodology, P.P. and G.S.; software, G.S.; formal analysis, G.S.; data curation, E.D.G., M.M. and P.P.; writing-original draft preparation, F.B., E.D.G. and P.P.; writing-review and editing, L.C., P.P., M.M. and G.S. All authors have read and agreed to the published version of the manuscript.

Funding: This research received no external funding.

Conflicts of Interest: The authors declare no conflict of interest.

\section{Appendix A}

Table A1. Table reporting the excluded studies and reasons for exclusion.

\begin{tabular}{cc}
\hline Article Excluded & Reason for Exclusion \\
\hline Shon et al., 2013 [30] & Specimens material (zirconia implants) \\
Naujok et al., 2019 [31] & Sample size \\
Aita H et al., 2009 [32] & Outcome \\
Suzuki T et al., 2009 [13] & Outcome \\
Ueno T et al., 2010 [33] & Outcome \\
Ueno T et al., 2010 [34] & Outcome \\
\hline
\end{tabular}


Table A1. Cont.

\begin{tabular}{cc}
\hline Article Excluded & Reason for Exclusion \\
\hline Minamikaw et al., 2014 [35] & Outcome \\
Hirota M et al., 2016 [36] & Sample size \\
Ishijima M et al., 2016 [37] & Outcome \\
Soltanzadeh P et al., 2017 [38] & Outcome \\
Sugita Y et al., 2014 [39] & Outcome \\
Taniyama et al., 2020 [40] & Outcome \\
Jimbo R et al., 2011 [41] & Specimens \\
Hayashi M et al., 2014 [42] & Specimens \\
Yamazaki M et al., 2015 [43] & Outcome \\
Kim H.S et al., 2017 [44] & Farmacological treatment (alendronate) \\
Lee J.B et al., 2019 [45] & Sample size \\
Miki T et al., 2019 [46] & Specimens \\
Hirakawa et al., 2013 [47] & Surface treatment \\
Pyo et al., 2013 [48] & Sample size \\
Ishii et al., 2016 [49] & Outcome \\
Mehl et al. 2018 [50] & Sample size \\
Funato et al., 2013 [51] & Case series \\
Suzuki et al., 2013 [52] & Retrospective analysis \\
Funato et al., 2013 [53] & Complex cases \\
Kitajima et al., 2016 [54] & Outcome \\
Hirota et al., 2016 [55] & Specimens \\
Hirota et al., 2018 [56] & \\
Puisys et al., 2018 [57] & Cross-sectional retrospective analysis \\
& Complions
\end{tabular}

\section{References}

1. Moraschini, V.; Poubel, L.A.; Ferreira, V.F.; Edos, B.S. Evaluation of survival and success rates of dental implants reported in longitudinal studies with a follow-up period of at least 10 years: A systematic review. Int. J. Oral Maxillofac. Surg. 2015, 44, 377-388. [CrossRef] [PubMed]

2. Zita Gomes, R.; de Vasconcelos, M.R.; Lopes Guerra, I.M.; de Almeida, R.A.B.; de Campos Felino, A.C. Implant stability in the posterior maxilla: A controlled clinical trial. Biomed. Res. Int. 2017, 2017, 6825213. [CrossRef] [PubMed]

3. Albrektsson, T.; Jemt, T.; Molne, J.; Tengvall, P.; Wennerberg, A. On inflammation-immunological balance theory-A critical apprehension of disease concepts around implants: Mucositis and marginal bone loss may represent normal conditions and not necessarily a state of disease. Clin. Implant Dent. Relat. Res. 2019, 21, 183-189. [CrossRef]

4. Albrektsson, T.; Chrcanovic, B.; Molne, J.; Wennerberg, A. Foreign body reactions, marginal bone loss and allergies in relation to titanium implants. Eur. J. Oral Implantol. 2018, 11, S37-S46. [PubMed]

5. Jemat, A.; Ghazali, M.J.; Razali, M.; Otsuka, Y. Surface modifications and their effects on titanium dental implants. BioMed Res. Int. 2015, 2015, 791725. [CrossRef] [PubMed]

6. Conserva, E.; Menini, M.; Ravera, G.; Pera, P. The role of surface implant treatments on the biological behavior of SaOS-2 osteoblast-like cells. An in vitro comparative study. Clin. Oral Implants Res. 2013, 24, 880-889. [CrossRef]

7. Conserva, E.; Lanuti, A.; Menini, M. Cell behavior related to implant surfaces with different microstructure and chemical composition: An in vitro analysis. Int. J. Oral Maxillofac. Implants 2010, 25, 1099-1107.

8. Menini, M.; Dellepiane, E.; Chvartszaid, D.; Baldi, D.; Schiavetti, I.; Pera, P. Influence of different surface Characteristics on Peri-implant tissue behavior: A six-year prospective report. Int. J. Prosthodont. 2015, 28, 389-395. [CrossRef]

9. Alharbi, H.M.; Babay, N.; Alzoman, H.; Basudan, S.; Anil, S.; Jansen, J.A. Bone morphology changes around two types of bone-level implants installed in fresh extraction sockets-A histomorphometric study in beagle dogs. Clin. Oral Implants Res. 2015, 26, 1106-1112. [CrossRef] 
10. Canullo, L.; Menini, M.; Santori, G.; Rakic, M.; Sculean, A.; Pesce, P. Titanium abutment surface modifications and peri-implant tissue behavior: A systematic review and meta-analysis. Clin. Oral Investig. 2020, 24, 1113-1124. [CrossRef]

11. Pesce, P.; Menini, M.; Tommasato, G.; Patini, R.; Canullo, L. Influence of modified titanium abutment surface on peri-implant soft tissue behaviour: A systematic review of histological findings. Int. J. Oral Implantol. 2019, 12, 419-429.

12. Mariscal-Munoz, E.; Costa, C.A.; Tavares, H.S.; Bianchi, J.; Hebling, J.; Machado, J.P.; Lerner, U.H.; Souza, P.P. Osteoblast differentiation is enhanced by a nano-to-microhybrid titanium surface created by Yb: YAG laser irradiation. Clin. Oral Investig. 2016, 20, 503-551. [CrossRef] [PubMed]

13. Suzuki, T.; Hori, N.; Att, W.; Kubo, K.; Iwasa, F.; Ueno, T.; Maeda, H.; Ogawa, T. Ultraviolet treatment overcomes time-related degrading bioactivity of titanium. Tissue Eng. A 2009, 15, 3679-3688. [CrossRef] [PubMed]

14. Att, W.; Hori, N.; Takeuchi, M.; Ouyang, J.; Yang, Y.; Anpo, M.; Ogawa, T. Time-dependent degradation of titanium osteoconductivity: An implication of biological aging of implant materials. Biomaterials 2009, 30, 5352-5536. [CrossRef]

15. Henningsen, A.; Smeets, R.; Hartjen, P.; Heinrich, O.; Heuberger, R.; Heiland, M.; Precht, C.; Cacaci, C. Photofunctionalization and non-thermal plasma activation of titanium surfaces. Clin. Oral Investig. 2018, 22, 1045-1054. [CrossRef]

16. Canullo, L.; Genova, T.; Tallarico, M.; Gautier, G.; Mussano, F.; Botticelli, D. Plasma of argon affects the earliest biological response of different implant surfaces: An in vitro comparative study. J. Dent. Res. 2016, 95, 566-573. [CrossRef]

17. Canullo, L.; Genova, T.; Gross Trujillo, E.; Pradies, G.; Petrillo, S.; Muzzi, M.; Carossa, S.; Mussano, F. Fibroblast interaction with different abutment surfaces: In vitro study. Int. J. Mol. Sci. 2020, 21, 1919. [CrossRef]

18. Moher, D.; Liberati, A.; Tetzlaff, J.; Altman, D.G. PRISMA Group. Preferred reporting items for systematic reviews and meta-analyses: The PRISMA statement. PLoS Med. 2009, 6, e1000097. [CrossRef]

19. Hooijmans, C.R.; Rovers, M.M.; de Vries, R.B.; Leenaars, M.; Ritskes-Hoitinga, M.; Langendam, M.W. SYRCLE's risk of bias tool for animal studies. BMC Med. Res. Methodol. 2014, 14, 43. [CrossRef]

20. Shen, J.; Liu, J.; Chen, X.; Wang, X.; He, F.; Wang, H. The In Vivo Bone Response of Ultraviolet-Irradiated Titanium Implants Modified with Spontaneously Formed Nanostructures: An Experimental Study in Rabbits. Int. J. Oral Maxillofac. Implants 2016, 31, 776-784. [CrossRef]

21. Coelho, P.G.; Giro, G.; Teixeira, H.S.; Marin, C.; Witek, L.; Thompson, V.P.; Tovar, N.; Silva, N.R. Argon-based atmospheric pressure plasma enhances early bone response to rough titanium surfaces. J. Biomed. Mater. Res. A 2012, 100, 1901-1906. [CrossRef] [PubMed]

22. Teixeira, H.S.; Marin, C.; Witek, L.; Freitas Jr, A.; Silva, N.R.; Lilin, T.; Tovar, N.; Janal, M.N.; Coelho, P.G. Assessment of a chair-side argon-based non-thermal plasma treatment on the surface characteristics and integration of dental implants with textured surfaces. J. Mech. Behav. Biomed. Mater. 2012, 9, 45-49. [CrossRef] [PubMed]

23. Giro, G.; Tovar, N.; Witek, L.; Marin, C.; Silva, N.R.; Bonfante, E.A.; Coelho, P.G. Osseointegration assessment of chairside argon-based non thermal plasma-treated Ca-P coated dental implants. J. Biomed. Mater. Res. A 2013, 101, 98-103. [CrossRef]

24. Canullo, L.; Tallarico, M.; Botticelli, D.; Alccayhuaman, K.A.A.; Martins Neto, E.C.; Xavier, S.P. Hard and soft tissue changes around implants activated using plasma of argon: A histomorphometric study in dog. Clin. Oral Implants Res. 2018, 29, 389-395. [CrossRef] [PubMed]

25. Hung, Y.W.; Chen, H.L.; Lee, L.T.; Tung, K.C.; Bau, D.T.; Wong, Y.K. Effects of non-thermal plasma on sandblasted titanium dental implants in beagle dogs. J. Chin. Med Assoc. 2018, 81, 920-925. [CrossRef] [PubMed]

26. Sawase, T.; Jimbo, R.; Baba, K.; Shibata, Y.; Ikeda, T.; Atsuta, M. Photo-induced hydrophilicity enhances initial cell behavior and early bone apposition. Clin. Oral Implants Res. 2008, 19, 491-496. [CrossRef]

27. Park, K.H.; Koak, J.Y.; Kim, S.K.; Han, C.H.; Heo, S.J. The effect of ultraviolet-C irradiation via a bactericidal ultraviolet sterilizer on an anodized titanium implant: A study in rabbits. Int. J. Oral Maxillofac. Implants 2013, 28, 57-66. [CrossRef] 
28. Yamauchi, R.; Itabashi, T.; Wada, K.; Tanaka, T.; Kumagai, G.; Ishibashi, Y. Photofunctionalised Ti6Al4V implants enhance early phase osseointegration. Bone Jt. Res. 2017, 6, 331-336. [CrossRef]

29. Sanchez-Perez, A.; Cachazo-Jiménez, C.; Sánchez-Matás, C.; Martín-de-Llano, J.J.; Davis, S.; Carda-Batalla, C. Effects of Ultraviolet Photoactivation on Osseointegration of Commercial Pure Titanium Dental Implant After 8 Weeks in a Rabbit Model. J. Oral Implantol. 2020, 46, 101-107. [CrossRef]

30. Shon, W.J.; Chung, S.H.; Kim, H.K.; Han, G.J.; Cho, B.H.; Park, Y.S. Peri-implant bone formation of non-thermal atmospheric pressure plasma-treated zirconia implants with different surface roughness in rabbit tibiae. Clin. Oral Implants Res. 2014, 25, 573-579. [CrossRef]

31. Naujokat, H.; Harder, S.; Schulz, L.Y.; Wiltfang, J.; Flörke, C.; Açil, Y. Surface conditioning with cold argon plasma and its effect on the osseointegration of dental implants in miniature pigs. J. Craniomaxillofac. Surg. 2019, 47, 484-490. [CrossRef] [PubMed]

32. Aita, H.; Hori, N.; Takeuchi, M.; Suzuki, T.; Yamada, M.; Anpo, M.; Ogawa, T. The effect of ultraviolet functionalization of titanium on integration with bone. Biomaterials 2009, 30, 1015-1025. [CrossRef] [PubMed]

33. Ueno, T.; Yamada, M.; Hori, N.; Suzuki, T.; Ogawa, T. Effect of ultraviolet photoactivation of titanium on osseointegration in a rat model. Int. J. Oral Maxillofac. Implants 2010, 25, 287-294. [PubMed]

34. Ueno, T.; Yamada, M.; Suzuki, T.; Minamikawa, H.; Sato, N.; Hori, N.; Takeuchi, K.; Hattori, M.; Ogawa, T. Enhancement of bone-titanium integration profile with UV-photofunctionalized titanium in a gap healing model. Biomaterials 2010, 31, 1546-1557. [CrossRef]

35. Minamikawa, H.; Ikeda, T.; Att, W.; Hagiwara, Y.; Hirota, M.; Tabuchi, M.; Aita, H.; Park, W.; Ogawa, T. Photofunctionalization increases the bioactivity and osteoconductivity of the titanium alloy Ti6Al4V. J. Biomed. Mater. Res. A 2014, 102, 3618-3630. [CrossRef]

36. Hirota, M.; Tanaka, M.; Ishijima, M.; Iwasaki, C.; Park, W.; Ogawa, T. Effect of photofunctionalization on Ti6Al4V screw stability placed in segmental bone defects in rat femurs. J. Oral Maxillofac. Surg. 2016, 74, 861.e1-861.e16. [CrossRef]

37. Ishijima, M.; Ghassemi, A.; Soltanzadeh, P.; Tanaka, M.; Nakhaei, K.; Park, W.; Hirota, M.; Tsukimura, N.; Ogawa, T. Effect of UV Photofunctionalization on Osseointegration in Aged Rats. Implant Dent. 2016, 25, 744-750. [CrossRef]

38. Soltanzadeh, P.; Ghassemi, A.; Ishijima, M.; Tanaka, M.; Park, W.; Iwasaki, C.; Hirota, M.; Ogawa, T. Success rate and strength of osseointegration of immediately loaded UV-photofunctionalized implants in a rat model. J. Prosthet. Dent. 2017, 118, 357-362. [CrossRef]

39. Sugita, Y.; Honda, Y.; Kato, I.; Kubo, K.; Maeda, H.; Ogawa, T. Role of photofunctionalization in mitigating impaired osseointegration associated with type 2 diabetes in rats. Int. J. Oral Maxillofac. Implants 2014, 29, 1293-1300. [CrossRef]

40. Taniyama, T.; Saruta, J.; Mohammadzadeh Rezaei, N.; Nakhaei, K.; Ghassemi, A.; Hirota, M.; Okubo, T.; Ikeda, T.; Sugita, Y.; Hasegawa, M.; et al. UV-Photofunctionalization of Titanium Promotes Mechanical Anchorage in A Rat Osteoporosis Model. Int. J. Mol. Sci. 2020, 21, 1235. [CrossRef]

41. Jimbo, R.; Ono, D.; Hirakawa, Y.; Odatsu, T.; Tanaka, T.; Sawase, T. Accelerated photo-induced hydrophilicity promotes osseointegration: An animal study. Clin. Implant Dent. Relat. Res. 2011, 13, 79-85. [CrossRef]

42. Hayashi, M.; Jimbo, R.; Xue, Y.; Mustafa, K.; Andersson, M.; Wennerberg, A. Photocatalytically induced hydrophilicity influences bone remodelling at longer healing periods: A rabbit study. Clin. Oral Implants Res. 2014, 25, 749-754. [CrossRef]

43. Yamazaki, M.; Yamada, M.; Ishizaki, K.; Sakurai, K. Ultraviolet-C irradiation to titanium implants increases peri-implant bone formation without impeding mineralization in a rabbit femur model. Acta Odontol. Scand. 2015, 73, 302-311. [CrossRef] [PubMed]

44. Kim, H.S.; Lee, J.I.; Yang, S.S.; Kim, B.S.; Kim, B.C.; Lee, J. The effect of alendronate soaking and ultraviolet treatment on bone-implant interface. Clin. Oral Implants Res. 2017, 28, 1164-1172. [CrossRef]

45. Lee, J.B.; Jo, Y.H.; Choi, J.Y.; Seol, Y.J.; Lee, Y.M.; Ku, Y.; Rhyu, I.C.; Yeo, I.S.L. The effect of ultraviolet photofunctionalization on a titanium dental implant with machined surface: An in vitro and in vivo study. Materials 2019, 12, 2078. [CrossRef] [PubMed]

46. Miki, T.; Matsuno, T.; Hashimoto, Y.; Miyake, A.; Satomi, T. In vitro and in vivo evaluation of titanium surface modification for biological aging by electrolytic reducing ionic water. Appl. Sci. 2019, 9, 713. [CrossRef] 
47. Hirakawa, Y.; Jimbo, R.; Shibata, Y.; Watanabe, I.; Wennerberg, A.; Sawase, T. Accelerated bone formation on photo-induced hydrophilic titanium implants: An experimental study in the dog mandible. Clin. Oral Implants Res. 2013, 24, 139-144. [CrossRef]

48. Pyo, S.W.; Park, Y.B.; Moon, H.S.; Lee, J.H.; Ogawa, T. Photofunctionalization enhances bone-implant contact, dynamics of interfacial osteogenesis, marginal bone seal, and removal torque value of implants: A dog jawbone study. Implant Dent. 2013, 22, 666-675. [CrossRef]

49. Ishii, K.; Matsuo, M.; Hoshi, N.; Takahashi, S.S.; Kawamata, R.; Kimoto, K. Effect of ultraviolet irradiation of the implant surface on progression of Periimplantitis-A pilot study in dogs. Implant Dent. 2016, 25, 47-53. [CrossRef]

50. Mehl, C.; Kern, M.; Neumann, F.; Bähr, T.; Wiltfang, J.; Gassling, V. Effect of ultraviolet photofunctionalization of dental titanium implants on osseointegration. J. Zhejiang Univ. Sci. B 2018, 19, 525-534. [CrossRef]

51. Funato, A.; Ogawa, T. Photofunctionalized dental implants: A case series in compromised bone. Int. J. Oral Maxillofac. Implants 2013, 28, 1589-1601. [CrossRef] [PubMed]

52. Suzuki, S.; Kobayashi, H.; Ogawa, T. Implant stability change and osseointegration speed of immediately loaded photofunctionalized implants. Implant Dent. 2013, 22, 481-490. [CrossRef] [PubMed]

53. Funato, A.; Yamada, M.; Ogawa, T. Success rate, healing time, and implant stability of photofunctionalized dental implants. Int. J. Oral Maxillofac. Implants. 2013, 28, 1261-1271. [CrossRef]

54. Kitajima, H.; Ogawa, T. The use of photofunctionalized implants for low or extremely low primary stability cases. Int. J. Oral Maxillofac. Implants 2016, 31, 439-447. [CrossRef]

55. Hirota, M.; Ozawa, T.; Iwai, T.; Ogawa, T.; Tohnai, I. Implant stability development of photofunctionalized implants placed in regular and complex cases: A case-control study. Int. J. Oral Maxillofac. Implants 2016, 31, 676-686. [CrossRef]

56. Hirota, M.; Ozawa, T.; Iwai, T.; Ogawa, T.; Tohnai, I. Effect of Photofunctionalization on Early Implant Failure. Int. J. Oral Maxillofac. Implants 2018, 33, 1098-1102. [CrossRef] [PubMed]

57. Puisys, A.; Schlee, M.; Linkevicius, T.; Petrakakis, P.; Tjaden, A. Photo-activated implants: A triple-blinded, split-mouth, randomized controlled clinical trial on the resistance to removal torque at various healing intervals. Clin. Oral Investig. 2020, 24, 1789-1799. [CrossRef]

58. Annunziata, M.; Canullo, L.; Donnarumma, G.; Caputo, P.; Nastri, L.; Guida, L. Bacterial inactivation/sterilization by argon plasma treatment on contaminated titanium implant surfaces: In vitro study. Med. Oral Patol. Oral Cir. Bucal 2016, 1, e118-e121. [CrossRef]

59. Canullo, L.; Genova, T.; Pesce, P.; Nakajima, Y.; Yonezawa, D.; Mussano, F. Surface bio-functionalization using plasma of Argon could alter microbiologicaland topographic surface analysis of dental implants? Ann. Anat. 2020, 230, 151489. [CrossRef]

60. Genova, T.; Pesce, P.; Mussano, F.; Tanaka, K.; Canullo, L. The influence of bone-graft biofunctionalization with plasma of argon on bacterial contamination. J. Biomed. Mater. Res. Part. A 2019, 107, 67-70. [CrossRef]

61. Canullo, L.; Genova, T.; Rakic, M.; Sculean, A.; Miron, R.; Muzzi, M.; Carossa, S.; Mussano, F. Effects of argon plasma treatment on the osteoconductivity of bone grafting materials. Clin. Oral Investig. 2020, 24, 2611-2623. [CrossRef] [PubMed]

62. Hirota, A.; Yamada, Y.; Canullo, L.; Xavier, S.P.; Baba, S. Bioactivation of bovine bone matrix using argon plasma: An experimental study for sinus augmentation in rabbits. Int. J. Oral Maxillofac. Implants 2020, 35, 731-738. [CrossRef] [PubMed]

63. Makary, C.; Rebaudi, A.; Sammartino, G.; Naaman, N. Implant primary stability determined by resonance frequency analysis: Correlation with insertion torque, histologic bone volume, and torsional stability at 6 weeks. Implant Dent. 2012, 21, 474-480. [CrossRef] [PubMed]

(C) 2020 by the authors. Licensee MDPI, Basel, Switzerland. This article is an open access article distributed under the terms and conditions of the Creative Commons Attribution (CC BY) license (http://creativecommons.org/licenses/by/4.0/). 